\title{
The total weight of mineral in the human infant
}

\author{
By J. S. GARROW AND K. FLETCHER \\ Medical Research Council, Tropical Metabolism Research Unit, \\ University of the West Indies, famaica
}

(Received 10 February 1964-Accepted 13 April 1964)

There is at present no satisfactory method by which the severity of protein depletion in malnourished children can be measured. Although there are numerous methods for the estimation of body composition, these rely to a greater or lesser extent on a constant ratio between some of the four main body constituents: water, protein, fat and mineral. In infantile malnutrition the assumption of any such ratio is unjustified, since variations in each of the constituents may be large and independent of changes in the others. Of the four, only water can be measured independently by a dilution technique. However, if the total weight of one of the three solid components is also known, the proportion of the other two can be estimated from the density of the body (Behnke, 1961).

We are trying to measure the body composition of malnourished children, and this paper presents a method for the estimation of total bone mineral and the results obtained for eight Jamaican children of various nutritional states.

\section{EXPERIMENTAL \\ Clinical material}

The eight children were patients either in the Tropical Metabolism Research Unit or in the paediatric wards of the University College Hospital. Their ages, weights and heights are shown in Table 1 . Children I, 5 and 6 suffered from kwashiorkor and died within $36 \mathrm{~h}$ of admission to the ward. Child 2 had been treated for severe malnutrition for 7 weeks and had been making good progress, but she developed measles and broncho-pneumonia, and died suddenly. Children 3 and 8 were both outpatients who had been successfully treated for malnutrition and who had died from gastroenteritis at home. Child 4 was a nephrotic who died in hospital. Child 7 was brought into hospital moribund with a severe septicaemia. Thus Children I, 4, 5 and 6 were severely malnourished, child 2 moderately so, and children 3,7 and 8 were clinically well nourished. In the table they have been arranged in order of increasing bone weight.

The parents of these children gave their bodies to the Anatomy Department of the University of the West Indies, from which we obtained material for analysis.

\section{Analytical methods}

$X$-ray densitometry of bone. The X-ray opacity of the shaft of the tibia and of the adjacent soft tissues was estimated by comparing, on the X-ray film, the light transmitted through the image of the bone, of the adjacent soft tissue, and of a standard. 
The standard was a block of aluminium in which were cut twelve steps of thickness varying from 0.01 to $1.00 \mathrm{~cm}$. It was placed on the X-ray film and X-rayed at the same time as the leg. The developed film was placed on an $\mathrm{X}$-ray viewing screen, and the transmitted light was measured over a circle $3 \mathrm{~mm}$ in diameter by means of a Mullard ORP 60 photoresistor mounted in the tip of a small brass tube. The photoresistor was wired in series with a mirror galvanometer and a $3 \mathrm{~V}$ battery across a $0.5 \mathrm{M} \Omega$ potentiometer. With this system the galvanometer is set to zero with the photoresistor applied to the dark background of the $\mathrm{X}$-ray film, and the potentiometer is set to give approximately full-scale deflexion when the photoresistor is applied to the least dense part of the film which is to be measured. It was found that the galvanometer deflexion was directly proportional to the thickness of the steps in the aluminium standard over the range $0.01-0.6 \mathrm{~cm}$ and the readings for bone and soft tissue always fell within this range. Care was taken to place the photoresistor over the centre of the shaft of the tibia so that the light passing through the image of the cortex at the edge of the bone was not measured.

The reading over bone minus that over adjacent soft tissue is expressed in terms of $\mathrm{cm}$ of aluminium $(D)$.

Chemical determination of bone mineral. The body was divided sagittally and the right half was taken for analysis. Protein and fat were removed by boiling the bone in $2 \mathrm{~N}-\mathrm{NaOH}$ and the remaining mineral was filtered, washed, dried in an oven at $105^{\circ}$ and weighed. To ensure that protein and fat had been completely removed, the bone mineral was then dissolved in dilute hydrochloric acid and the resultant solution was analysed for nitrogen (by Kjeldahl) and for fat by extraction with petrol. In all samples the nitrogen content of the dried mineral was negligible, but a small amount of fat was found, and its weight was subtracted to obtain a true weight of bone mineral for the half skeleton.

\section{RESULTS}

The results are summarized in Table $\mathrm{I}$.

It was assumed that the total bone mineral of a child could be calculated from the three variables: (I) height of the child in $\mathrm{cm}, H$; (2) length of the tibia in $\mathrm{cm}, L$; and (3) the $\mathrm{X}$-ray opacity of the bone in $\mathrm{cm}$ of aluminium, $D$. The formula relating $W$, the observed weight of bone mineral to these three variables, was assumed to be of the form

$$
W=A H^{\alpha} L^{\beta} D^{\gamma}+K,
$$

where $A, K, \alpha, \beta$ and $\gamma$ are constants. Regression analysis showed the value of $K$ to be zero and

$$
W={ }_{1}^{0.6573} H^{0 \cdot 1045} L^{1 \cdot 7248} D^{0.5360} .
$$

From this equation was derived the simplified formula $W=3.30 L^{2} D^{0.5}$, which was used to calculate the values shown in Table $\mathrm{r}$. Also shown are the differences of these values from those found by chemical analysis, botin in $g$ and also as a percentage of the weight of bone mineral. The maximum difference was $16.3 \%$ and the mean difference $10.5 \%$. 
Table I. Results of the estimation, by $X$-ray densitometry, of total bone mineral in eight children after death, and their comparison with those obtained by chemical analysis

\begin{tabular}{|c|c|c|c|c|c|c|c|c|}
\hline Subject no.... & I & 2 & 3 & 4 & 5 & 6 & 7 & 8 \\
\hline Age (months) & 6 & 14 & IO & II & 16 & 14 & 9 & I3 \\
\hline Body-weight $(\mathrm{kg})$ & $4: 10$ & $4 \cdot 17$ & $4 \cdot 69$ & $7 \cdot 60$ & 6.70 & 5.67 & $7 \cdot 50$ & $7 \cdot 70$ \\
\hline Height $(H)(\mathrm{cm})$ & 55 & 58 & 57 & 70 & $6_{5}$ & 67 & 65 & 71 \\
\hline $\begin{array}{l}\text { Length of tibia }(L) \\
(\mathrm{cm})\end{array}$ & $8 \cdot 3$ & $9 \cdot 1$ & $8 \cdot 9$ & $10 \cdot 1$ & $1 I \cdot 0$ & 10.3 & 10.1 & $11 \cdot 5$ \\
\hline $\begin{array}{l}\text { Opacity of tibia }(D) \\
\text { (cm aluminium) }\end{array}$ & 0.088 & 0.090 & 0.083 & 0.115 & 0.122 & 0.118 & 0.175 & 0.140 \\
\hline $\begin{array}{l}\text { Total bone mineral } \\
\text { by chemical analysis } \\
(A)(\mathrm{g})\end{array}$ & 74 & 76 & 90 & 109 & 126 & 134 & 148 & 190 \\
\hline $\begin{array}{l}\text { Bone mineral as \% } \\
\text { body-weight }\end{array}$ & $1 \cdot 80$ & $I \cdot 82$ & $I \cdot 92$ & $1 \cdot 44$ & $1 \cdot 88$ & $2 \cdot 37$ & $I \cdot 97$ & $2 \cdot 47$ \\
\hline $\begin{array}{l}\text { Total bone mineral } \\
\text { by calculation from } \\
\text { formula }(W)(\mathrm{g})\end{array}$ & $67 \cdot 5$ & $82 \cdot 0$ & $75 \cdot 3$ & $117 \cdot 6$ & $139^{\circ} 4$ & $152 \cdot 0$ & $140 \cdot 6$ & $163 \cdot 0$ \\
\hline $\begin{array}{l}\text { Difference between } \\
\text { estimates }(A-W)(\mathrm{g})\end{array}$ & +6.5 & $-6 \cdot 0$ & +147 & $-8 \cdot 6$ & $-13 \cdot 4$ & $-18 \cdot 0$ & $+7 \cdot 4$ & $+27 \cdot 0$ \\
\hline Difference as $\%$ of $A$ & +8.8 & $-7 \cdot 9$ & $+16 \cdot 3$ & $-7 \cdot 9$ & $-10 \cdot 6$ & -13.4 & +5 & $+14 \cdot 2$ \\
\hline
\end{tabular}

Table 2. (A) Body composition of a hypothetical child weighing $6 \mathrm{~kg}$ with a density of 1.041 , body water of $3.9 \mathrm{l}$. and $120 \mathrm{~g}$ of bone mineral and $(B)$ effect on estimates of contents of protein and fat if the content of bone mineral in this child is overestimated by $20 \%$

\begin{tabular}{|c|c|c|c|c|c|}
\hline \multirow[b]{2}{*}{ Component } & \multirow[b]{2}{*}{$\begin{array}{l}\text { Density } \\
(\mathrm{g} / \mathrm{ml})\end{array}$} & \multicolumn{2}{|c|}{$A$} & \multicolumn{2}{|c|}{$B$} \\
\hline & & $\begin{array}{l}\text { Weight } \\
\text { (g) }\end{array}$ & $\begin{array}{l}\text { Volume } \\
\text { (ml) }\end{array}$ & $\begin{array}{l}\text { Weight } \\
\text { (g) }\end{array}$ & $\begin{array}{l}\text { Volume } \\
\text { (ml) }\end{array}$ \\
\hline $\begin{array}{l}\text { Water } \\
\text { Mineral : bone } \\
\quad \text { soluble }\end{array}$ & $\begin{array}{l}0.993 \\
3.000 \\
2.000\end{array}$ & $\begin{array}{r}3900 \\
120 \\
39\end{array}$ & $\begin{array}{r}3927 \\
40 \\
19\end{array}$ & $\begin{array}{r}3900 \\
144 \\
39\end{array}$ & $\begin{array}{r}3927 \\
48 \\
19\end{array}$ \\
\hline $\begin{array}{l}\text { Protein } \\
\text { Fat }\end{array}$ & $\begin{array}{l}I \cdot 340 \\
0.900\end{array}$ & $\begin{array}{r}1038 \\
903\end{array}$ & $\begin{array}{r}770 \\
1008\end{array}$ & $\begin{array}{l}985 \\
932\end{array}$ & $\begin{array}{r}735 \\
1035\end{array}$ \\
\hline Whole body & $\mathrm{I} \cdot 04 \mathrm{I}$ & 6000 & 5764 & 6000 & 5764 \\
\hline
\end{tabular}

\section{DISCUSSION}

We have found that bone mineral accounts for about $2 \%$ of the body-weight of a child between the ages of 6 and 14 months. The remaining mineral is in solution in body water, and is about $\mathrm{I} \%$ of the weight of body water. The effect of a $20 \%$ error in the estimation of bone mineral on the estimation of total body composition is shown by considering the following hypothetical example:

A child who weighs $6000 \mathrm{~g}$ is found to have a total body water of $3900 \mathrm{~g}$ and a density of $\mathrm{r} \cdot 04 \mathrm{r}$. His bone mineral is estimated to be $120 \mathrm{~g}$. The total body composition is therefore shown in Table $2 A$.

If the bone mineral had been overestimated by $20 \%$ the calculated composition would be as in Table $2 \mathrm{~B}$. Thus an error of $20 \%$ in the estimate of bone mineral produces an error of about $5 \%$ in the estimate of protein, and a smaller error in the 
estimate of fat. This error is of a similar size to that which arises from a $3 \%$ error in the estimation of body water or an error of $0.3 \%$ in the estimation of body volume and hence density.

\section{SUMMARY}

I. It was found by chemical analysis of bodies of eight children between 6 and 14 months old that bone mineral accounted for an average of $2.0 \%$ of total bodyweight (range $\mathrm{r} \cdot 4-2 \cdot 5 \%$ ).

2. A simple method is described for measuring the $X$-ray opacity of the shaft of the tibia. It was found that from this value, and the length of the tibia, a value for the weight of total bone mineral of the child could be calculated, which did not differ by more than $17 \%$ from the weight of bone mineral as found by chemical analysis.

3. This degree of accuracy was adequate for the determination of total body protein and fat in these children from their density.

We are grateful to Dr D. A. N. Hoyte, Department of Anatomy, University of the West Indies, who enabled us to obtain the material for these analyses. We would also like to thank Dr R. Read of the Department of Mathematics, and Dr H. Lovell of the Medical Research Council Epidemiological Research Unit, for assistance in the mathematical analysis.

\section{REFEREN CE}

Behnke, A. R. (1961). Ann. N.Y. Acad. Sci. 110, 118. 